\title{
Confirmed by the Research: There IS Sex in the Library!
}

\author{
by Pauletta Brown Bracy
}

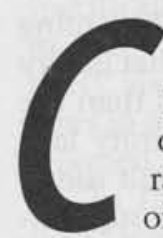

ensorship thrives in the boundless realm of public opinion. Unconfined by parameters, it pervades any aspect of American life. Dichotomies of what is right or wrong, good or bad, virtuous or decadent pose little problem for those who steadfastly hold to their positions in defending intellectual freedom or practicing censorship. Ultimately, both groups of citizens consider themselves acting in the best interest of the common good to either protect constitutional rights by ensuring access to information in varied format or to preserve the morality of the nation by eliminating and suppressing expressions of thought.

Research has documented the tremendous impact of this ongoing battle, and this article provides an overview of censorship in the state of North Carolina. At best, the research is minimal. Though many would attest that censorship does happen, for it is an all too familiar news report, the dearth of research on the topic suggests that it often is not documented. Existing findings and conclusions, however, serve to remind us of two important phenomena: (1) that intellectual freedom and censorship continue to be critical issues for other professions, and (2) that the incidence of censorship is on the rise and it is becoming increasingly successful.

\section{Revelations and Realities:}

\section{A Study of the Literature}

Two studies outside librarianship focused on journalism in high schools, and also the arts. Kathleen Douglass Phillips ex- amined freedom of press in North Carolina high schools. In a survey of statewide journalism teachers/newspaper advisors and case studies at three high schools, she confirmed that North Carolina high school journalists experience prior review, prior restraint, and censorship as basic tenets of their journalism education. ${ }^{1}$

A crisis in the arts labeled "culture war" led People For the American Way, a 300,000 member watchdog group that gauges censorship activity and regularly publishes findings of surveys, to begin monitoring challenges to artistic expression. Artistic Freedom Under Attack, Vol. 3 contains analyses of 104 nationwide cases that occurred in 1994 and were documented through a survey, arts publications, and press coverage. ${ }^{2}$ The prevalence in thirty-three states reflected an alarming successful censorship rate of seventy-eight percent. Sexuality or perceived sexual content in art headed the list as the basis for objection. ${ }^{3}$ of the three North Carolina case studies, two occurred in Durham and involved of photography and performance; the third incident, in Hudson, involved theater.

The nature of our profession in handling all kinds of information mandates the special attention that we pay to censorship. We have embraced allies in the classrooms of both pub- lic and private educational institutions that have found themselves victimized by the work of the censors. In an article prepared for Tar Heel Libraries last year, Gene Lanier, Chairman of the North Carolina Library Association Intellectual Freedom Committee, confirmed that challenges to library and classroom materials continue to rise in the state. ${ }^{4} \mathrm{Re}$ porting a total of fifty-two titles, he cited seven different locations of attacks. The greatest number of twenty-nine occurred in Charlotte. Chapel Hill followed with about half as many as the top-ranked Charlotte; and Asheboro, Canton, Durham, Goldsboro, and Elizabethtown had three or fewer complaints.

Employing mail survey and interview methodologies, People For the American Way in North Carolina ${ }^{5}$ sought to determine the scope of censorious activity among North Carolina English and Social Studies teachers. Two hun-
In a disturbing thirty-two percent success rate, censors removed or restricted the challenged materials. Geographically, teachers in fiftyone of the seventy-four counties [in North Carolina] reported cases; the greatest activity occurred in Wake and Guilford counties. 
dred and fifty-three teachers representing seventy-four counties responded to the survey conducted during the 19881989 school year. Selected follow-up interviews were conducted with thirty-six teachers from twenty-seven counties.

Data led the researchers to conclude in the report, School Censorship in North Carolina: Conflict in the Classroom, that censorship is a serious threat to North Carolina schools because more than twenty-five percent of the teachers surveyed indicated that they had faced challenges, and an additional ten percent who had not faced challenges knew of colleagues who had faced them. ${ }^{6}$ Topics of realistic and contemporary perspective including sex, religion, politics, and death were those most challenged. In a disturbing thirty-two percent success rate, censors removed or restricted the challenged materials. Geographically, teachers in fifty-one of the seventy-four counties [in North Carolina] reported cases; the greatest activity occurred in Wake and Guilford counties. A final conclusion consistent with most attempts to measure the scope of the problem is the practice of self-censorship or voluntary censorship. In this research, a number of teachers admitted that perceived pressure from school administrators and the community make them self-censor their teaching. ${ }^{7}$

Published in November 1990, People For the American Way in North Carolina's Censorship and SexEducation: A Survey of North Carolina Health Educators substantiated censorship and/or self-censorship as major concerns among 111 North Carolina health educators and health coordinators ${ }^{8}$ Birth control was reported as the most challenged subject matter among the health educators. Fifty percent of the respondent health coordinators reported that they had been challenged by a parent or told by a school official that a particular subject matter was inappropriate for the classroom. Results also revealed that although challenges sometimes result in censorship of existing curricula, more often the result is self-censorship of potential subjects by the educators themselves. ${ }^{9}$

Considering another aspect of the problems in the classroom, Mary Ann Weathers concentrated on the role of organizations that challenge curriculum materials and instructional strategies. Her doctoral dissertation, "An Investigation of the Impact of Special Interest Groups on Curriculum and Instruction in North Carolina 1983-1988," focused on K-12
North Carolina public schools during 1983-1988. ${ }^{10}$ Documenting the increased numbers of challenges, the targets of the challenges, and the predictable sources of the challenges, Weathers also described the impact of the main groups initiating the challenges - the Eagle Forum, the Conservative Evangelical Right, and the Ku Klux Klan. A final analysis considered the threat that pertinent beliefs of those groups pose to public education.

Since its founding in 1983, People For the American Way has conducted national annual surveys of censorship. Typically, data are collected through mail surveys and individual interviews with parents, librarians, teachers, and school administrators. The reports contain summaries of the findings, identification of trends, and case studies of statewide incidents. Statistics confirming the prevalence of censorship reflect only those cases reported and investigated. People For the American Way stresses that its reports offer only a brief synopsis of the problem because the clear majority of censorial activity is unreported.

Last year's report, Attacks on the Freedom to Learn, 1992-1993, ascertained that attacks continue to rise and challenges were successful in 41 percent of the cases. ${ }^{11}$ Nearly half of all reported challenges were to library books and the

\section{... although challenges sometimes result in censorship of existing curricula, more often the result is self-censorship of potential subjects by the educators themselves.}

most frequent rationale was for religious reasons. The second most cited complaint was sexual content. In the stateby-state analysis, North Carolina ranked 16 th, tied with three other states.

Much remained the same the following year except for the startling revelation of North Carolina's ranking. In the most current report, Attacks on the Freedom to Learn, 1993-1994, the state [North Carolina] ranked fourth nationally and experienced twice as many challenges as the previous year. A total of twenty-one incidents was con- firmed. ${ }^{12}$ Similarly on the national scene, censorship continued to rise, to the highest in the twelve year history of the report, with a success rate comparable to that of the previous year. The most frequent complaint lodged against materials, at a level of 31 percent, was that the treatment of sexuality was found to be offensive. ${ }^{13}$

Seeking public opinion regarding censorship, Ray L. Carpenter conducted a survey in Spring 1987 to determine the views of 497 North Carolinian adults about whether the local public libraries should remove books critical of church and religion from shelves. ${ }^{14}$ Seventy percent of those surveyed concurred that the library should not remove the books.

To further explore attitudes and examine differences between those who defend intellectual freedom and those who support censorship, respondents expressed opinions on civil liberty issues, sex, drugs, and alcohol. Regarding matters of sex, data revealed that library defenders are better informed than the censors about the state obscenity law, are more permissive about adult use of pornography, and are stronger supporters of freedom of speech and press where pornography is concerned. ${ }^{15}$

Both those who support intellectual freedom and those who support censorship strongly supported public school education about sex and AIDS, but considerably disagreed about the distribution of contraceptive information and products. Depicting sexual activity not identified in the context of "education" was viewed as obscene by large numbers in both groups, especially depictions of homosexual activity. About 25 percent of all respondents had seen an X-rated movie and approximately 30 percent had read a pornographic magazine. ${ }^{16}$

The emergent profile of those who defend intellectual freedom is of "a middle class, well educated, and generally tolerant majority". ${ }^{17}$

\section{Update of the Thorson Study}

In 1986, Barbara A. Thorson reviewed volumes of the American Library Association Office of Intellectual Freedom's Newsletter on Intellectual Freedom to present a brief overview of censorship from 1981 to 1986 in North Carolina. ${ }^{18}$ Based on reported incidents in the Newsletter, she provided statistical data on annual frequency, locations, complainants, reasons, affected institutions, and outcomes. In an effort to render a more current perspective, issues of the Newsletter dated January 1985 through March 1995 were studied, replicating Thorson's 
categories of data.

The total number of cases reported during the time frame was forty-eight. The years of greatest activity were 1987 and 1994. (See Table I) A factor in the 1987 statistics could be the enactment of the state's pornography law which went into effect October 1, 1985. Under this version of the statue, "items are obscene if they violate local community standards as determined by a jury, and disseminating obscenity is punishable by up to three years in prison."19 Following subsequent lawsuits by eighty video dealers, the North Carolina Supreme Court ruled in July 1987 that the law was constitutional. It also was noted in the news report that the law was considered to be one of the toughest in the country. ${ }^{20}$ The least activity of one reported case was in 1989. For libraries, the most active years were 1987 and 1993; no incidents specifically involving libraries occurred in 1989 and 1995 to date. Comparatively, about half as many library cases as cases in other settings or situations were reported.

In Table I, "Other Setting or Situation" was established as a category to identify the variety of censorious activities including the classroom, where required reading that was deemed objectionable was often substituted with alternative titles. Videos used in instructional activities were also targeted. Student press was under attack in four incidents including newspapers as well as a literary magazine. Research previously described in this article illustrates the nature of this growing phenomenon.

Art exhibits constitute another category, within "Other Setting or Situation" and included challenges made in a non-public secondary school, an arts center, and a university. "Library Exhibit" was treated separately only to distinguish it momentarily from the "Library" category that centers on materials such as books, magazines, and audio-visuals, and to alert librarians about the potential for challenge in this generally uncontested area as well. (Otherwise, it is a case of library censorship.) The two cited cases occurred in Durham $^{21}$ and Hillsborough ${ }^{22}$ and both involved displays assem-bled for observance of gay and lesbian pride during the month of June.

Drama produced for school and interpretations facilitated in classroom activities were criticized for sexual content and religious reasons. Two incidents involved local newspapers and editorial censorship of syndicated cartoons.

A category called "Mass Movement"

TABLE I.

Number of Reported Cases by Year

\begin{tabular}{|cccc|}
\hline Year & Library & $\begin{array}{c}\text { Other Setting/ } \\
\text { Situation }\end{array}$ & Total \\
\hline $1985^{\star}$ & 1 & 1 & 2 \\
1986 & 1 & 2 & 3 \\
1987 & 4 & 4 & 8 \\
1988 & 1 & 2 & 3 \\
1989 & 0 & 1 & 1 \\
1990 & 1 & 4 & 5 \\
1991 & 2 & 3 & 5 \\
1992 & 2 & 4 & 6 \\
1993 & 4 & 3 & 7 \\
1994 & 1 & 7 & 8 \\
$1995^{\star *}$ & 0 & 0 & 0 \\
TOTAL & 17 & 31 & 48 \\
\hline
\end{tabular}

* The Thorson study coveringJanuaryand March reported two incidents. No additional ones were reported for the remainder of the year.

** January and March only.

was created as a descriptor within "Other Setting or Situation" for collective efforts to censor. In one instance, grocery stores in Taylorsville were asked to remove five magazines that a group considered offensive "in content, antifamily, and objectionable to the general moral public." 23 A boycott of onestore was announced after it failed to comply. In the other circumstance, the Catawba County district attorney sent letters to record stores directing them to remove and stop sales of a record considered to be obscene. This action followed his review of the recording, prompted by a request from a Hickory minister. ${ }^{24}$ A similar kind of movement was a purgative fire that occurred in Hendersonville. Led by a minister in an antirock crusade, 125 to 150 people ritually burned album covers. ${ }^{25}$

Clothing was the center of controversy in an incident in which Durham junior high school students were suspended for displaying the Confederate flag. Lawsuits filed by parents on behalf of the students were settled and as a result, students were allowed to wear the battle flag. ${ }^{26}$

Finally, the involvement of a state agency was noted. The North Carolina Department of Environment, Health and Natural Resources destroyed 15,000 Spanish-language anti-AIDS brochures that graphically depicted how to use a condom. ${ }^{27}$ Disagreement over reasons why the brochures were destroyed fueled the controversy. A spokesperson for the agency said that the literature had been printed without proper review and denied that explicit content was a factor.

Regarding location, the incidents occurred in thirty different cities and counties throughout the state. (See Table II) The total number of five cases each was reported in Charlotte and Raleigh; Durham followed with four. The greatest frequency of one incident occurred in twenty locations.

In comparing this data to Thorson's, parents remained the most active complain-

\begin{tabular}{|ll|}
\hline TABLE II. & \\
Locations of & \\
Censorship Attempts \\
\hline Asheboro & 1 \\
Asheville & 1 \\
Burlington & 2 \\
Canton & 1 \\
Carthage & 1 \\
Chapel Hill & $2^{*}$ \\
Charlotte & $5^{\star}$ \\
Concord & 1 \\
Durham & $4^{*}$ \\
Eden & $1^{*}$ \\
Elizabethtown & $1^{*}$ \\
Fayetteville & $2^{*}$ \\
Forysth County & $1^{\star}$ \\
Gaston County & 1 \\
Goldsboro & $1^{*}$ \\
Hendersonville & 1 \\
Hickory & 1 \\
Hillsborough & 2 \\
Kinston & $1^{\star}$ \\
Lexington & 2 \\
Mount Pleasant & 1 \\
New Bern & 1 \\
Newton & 1 \\
Raleigh & 5 \\
Rockingham County & $1^{*}$ \\
Rutherfordton & $1^{*}$ \\
Taylorsville & $2^{\star}$ \\
Wake Forest & $1^{\star}$ \\
Watauga County & $1^{*}$ \\
Wilmington & $1^{*}$ \\
Winston-Salem & 1 \\
\hline library environment) & \\
\hline
\end{tabular}
ants. (See Table III) Numbers reflect multiple objectors in some cases. Second ranked organized efforts included such groups as Concerned Charlotteans, Alexander County Citizens for Decency, Right to Life, Bladen County Coalition of Christians, and Orange County Coalition Against Pornography. Students acted in concert with parents or individually to constitute the third ranked category of initiator of complaint.

In an atypical case of inclusion as opposed to exclusion, at a church meeting in Raleigh, the Reverend Jerry Falwell charged that the State Department of Public Instruction would not allow copies of Abortion and the Conscience of the Nation by Ronald Reagan to be donated to schools because of the Department's proabortion leadership. ${ }^{28} \mathrm{~A}$ Gaston County Right to Life chapter was unsuccessful in its attempts to donate the books to the county school libraries. A spokesperson from the 
TABLE III. Complainants/Sources of Complaints

\begin{tabular}{|c|c|}
\hline Complainant/Source & $\begin{array}{c}\text { \# of } \\
\text { Incidents }\end{array}$ \\
\hline 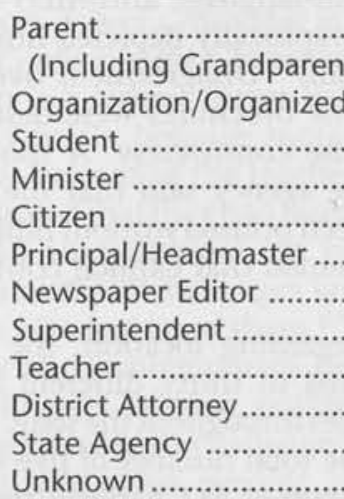 & 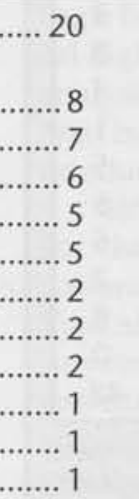 \\
\hline
\end{tabular}

agency explained that the state had no authority to place books in school libraries. Similarly, a Charlotte-based support group for gay youth complained about a Mount Pleasant High School production of $A$ Chorus Line because a gay character had been dropped from the script. ${ }^{29}$ Following an organized protest to have the character reinstated and a threatened lawsuit, the production was canceled before it opened.

\section{An examination of} the reasons for objections does indeed confirm that there is sex in the library

\begin{tabular}{|c|c|}
\hline Reason & $\begin{array}{l}\text { requency } \\
\text { Incidence }\end{array}$ \\
\hline Sexuality & 31 \\
\hline Religion & 6 \\
\hline Language & 4 \\
\hline Racism & 3 \\
\hline Politics & 2 \\
\hline Anti-Family Bias & 1 \\
\hline Death & 1 \\
\hline Literary Merit & 1 \\
\hline Morality & 1 \\
\hline Realism (Violence) & 1 \\
\hline Values & 1 \\
\hline Unknown & 1 \\
\hline
\end{tabular}

TABLE V. Institutions Involved in Censorship Attempts

\begin{tabular}{|c|c|}
\hline Institution & $\begin{array}{l}\text { Frequency of } \\
\text { Involvement }\end{array}$ \\
\hline \multicolumn{2}{|c|}{ High School .................................... 19} \\
\hline \multicolumn{2}{|c|}{ Middle/Junior High School ................. 9} \\
\hline \multicolumn{2}{|c|}{ Public Library ...................................... 9} \\
\hline \multicolumn{2}{|c|}{ Elementary School .............................. 4} \\
\hline \multicolumn{2}{|c|}{ College/University ............................... 2} \\
\hline \multicolumn{2}{|c|}{ Newspaper Company .......................... 2} \\
\hline \multicolumn{2}{|c|}{ Arts Center ...................................... 1} \\
\hline \multicolumn{2}{|c|}{ Community Movement (fire) .............. 1} \\
\hline \multicolumn{2}{|c|}{ Grocery Store .................................... 1} \\
\hline \multicolumn{2}{|c|}{ Non-Profit Center ................................ 1} \\
\hline \multicolumn{2}{|c|}{ Record Store ................................... 1} \\
\hline \multicolumn{2}{|c|}{ State Agency ................................... 1} \\
\hline
\end{tabular}

(and other places, as well). (See Table IV) Further defined for purposes of this analysis as homosexuality, lesbianism, AIDS, birth control, abortion, pornography, and rape, sex as a reason [for censorship] exceeded all other reasons combined. Religious objections e $\mathrm{n} \mathrm{com} \mathrm{p}$ a s s ed satanism, witchcraft, secular humanism, and using the Lord's name in vain. Language problems were mostlybecause of perceived profanity.

In a case of "Principal Discretion" involving high school press as well as sex as a reason, parents and a principal in Durham complained about an ad placed in the newspaper by a gay youth counseling group. ${ }^{30}$ In a compromise, the ad was relocated in an edition of the newspaper. Continuous complaints by parents led to total suppression by the principal. Literary merit was the basis of concern in Rutherford County. ${ }^{31}$ The school board voted unanimously not to remove Cabbage Patch Kids - The Just Right Family from elementary school library shelves. The citizen's complaint was that the book used ungrammatical writing.
TABLE VI.

Objects of Censorship

\section{Books}

Abortion and the Conscience of the Nation (Reagan)

Adventures of Huckleberry Finn (Twain)

Angel Dust Blues (Strasser)

Annie on My Mind (Garden)

Cabbage Patch Kids - The Just

Right Family (Callen)

The Color Purple (Walker)

Daddy's Roommate (Willhoite)

Eric (Lund)

Flowers for Algernon (Keyes)

The Grapes of Wrath (Steinbeck)

Heather Has Two Mommies (Newman)

I Know Why the Caged Bird Sings (Angelou)

I Want to Keep My Baby (Lee)

The Joy of Lesbian Sex (Comfort)

The Joy of Sex (Comfort)

Just So Stories (Kipling)

Loving Women (Falk)

The Martian Chronicles (Bradbury)

Naomi in the Middle (Klein)

Opus Pistorum (Miller)

Run, Shelley, Run (Samuels)

\section{Magazines}

Cosmopolitan

Glamour

Life

Mademoiselle

Playboy

Vogue

Audiovisual Materials

"Dice Man Rules" - Andrew Dice Clay (record)

"DeGrassi Junior High" series (video)

Unnamed Spanish-language video on sexuality

\section{Comics/Cartoon}

"Doonesbury" (Trudeau)

"Kudzu" (Malette)

\section{Drama}

Bats in the Belfry (Randazzo)

A Chorus Line (Bennett)

Table Settings (Lapine)

Student Press

Falcon Cry (Durham)

Paw Print (Raleigh)

Pirate's Hook (Durham)

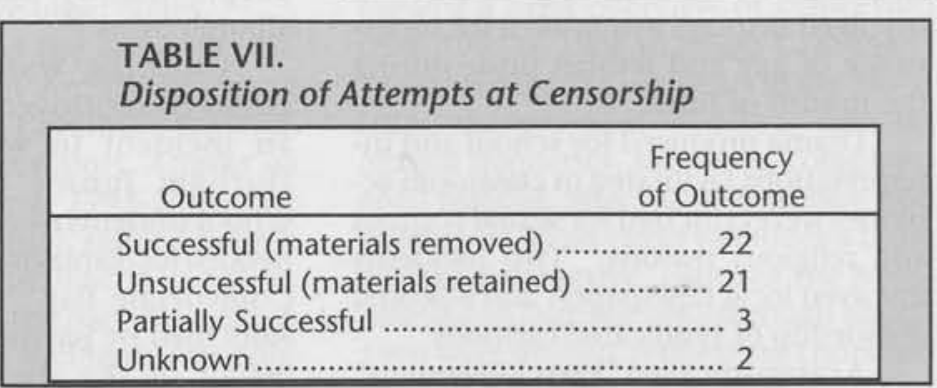


Of the institutions involved in cases, the high school was the most targeted environment, and was followed by the middle school/junior high school and public library which tied for second place. (See Table V) The elementary school was the next ranked setting. Compared to Thorson's study, this longer list reflects greater involvement of various types of institutions in attempts to censor.

Table VI contains data on the types and titles of materials involved in cases. The clear majority of books had one complaint, but The Color Purple, The Grapes of Wrath, Daddy's Roommate, and Heather Has Two Mommies had more than one complaint. With the exception of Playboy, the magazines cited were those referred to earlier in the "grocery store" case.

Resolutions of cases were categorized from the perspective of the censor. Of the reported cases, an almost equal number were successful in that the materials were removed and unsuccessful in that the materials were not removed. (See Table VII) In a couple of cases involving reading lists for the classroom, the titles were removed from the lists of required reading but retained in the school library media center. Such was the case in Lexington with $\mathrm{Eric}^{32}$ and in Randolph County with four videos in the "DeGrassi Junior High" public television series. ${ }^{33}$ Those cases in which students were given options to select other titles were considered "partially successful" because the titles became alternative choices instead of remaining the originally required books to read.

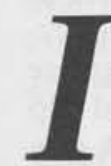
ndividual researchers, People For the American Way, and this up date of the Thorson examination have provided substantive evidence that our profession has cause for concern. It is incumbent upon us to remain diligent in our efforts to promote intellectual freedom and to be alert to the expanding magnitude of the problem of censorship. Of equal importance is for librarians to keep abreast of censorship as it occurs under all circumstances and not isolate ourselves within the confines of library facilities and limit our thinking within the theoretical framework which undergirds the profession. None of us as professionals and citizens is immune.

(Reports, other publications, videotapes and membership information from People For the American Way may be obtained by writing the office at $2000 \mathrm{M}$ Street, NW, Suite 400; Washington, DC or calling 202 467-4999.)

\section{References}

${ }^{1}$ Kathleen Douglass Phillips, "Free to Speak? The First Amendment and North Carolina High School Journalism (Censorship)," (Ph.D. diss., University of North Carolina at Chapel Hill, 1991). Dissertation Abstracts International vol. 52/10-A, page $346 \mathrm{~b}$.

2 People For the American Way, Artistic Freedom Under Attack, vol.3 (Washington, DC: People For the American Way, 1995), 7.

3 Ibid.

4 Gene D. Lanier, Tar Heel Libraries 17 (May/June 1994): 16.

${ }_{5}^{5}$ People For the American Way in North Carolina which was located in Raleigh closed in 1994.

6 People For the American Way in North Carolina, School Censorship in North Carolina: Conflict in the Classroom (Raleigh: People For the American Way in North Carolina, 1990), 4.

7 Ibid., 15.

8 People For The American Way in North Carolina, Censorship and Sex-Education: A Survey of North Carolina Health Edu- cators. (Raleigh: People For the American Way in North Carolina, 1990), 6.

9 Ibid., 11.

10 Mary Ann Weathers, "An Investigation of the Impact of Special Interest Groups on Curriculum and Instruction in North Carolina 1983-1988," (Ph.D. diss., University of North Carolina at Chapel Hill , 1990). Dissertation Abstracts International vol. 51/10-A, page 3323 .

11 People For the American Way, Attacks on the Freedom to Learn, 1992-1993 (Washington, DC: People For the American Way, 1993), 5.

12 People For the American Way, Attacks on the Freedom to Learn, 1993-1994 (Washington, DC: People For the American Way, 1994), 151.

13 Ibid., 13.

14 Ray L. Carpenter, "Censorship, Church, and Sex, "Library Journal 113 (October 15,1988$)$.

15 Ibid., 28.

16 Ibid.

17 Ibid.

18 Barbara A. Thorson, "Intellectual Freedom? Censorship in North Carolina, 1981-1985," North Carolina Libraries 44 (Winter 1986), 230-232.

19 Newsletter on Intellectual Freedom 35 (January 1986): 17.

20 Newsletter 36 (November 1987): 233.

21 Newsletter 35 (September 1986): 171 172.

22 Newsletter 42 (September 1993): 144-145.

23 Newsletter 37 (September 1988): 156.

24 Newsletter 40 (November 1991): 201.

25 Newsletter 39 (November 1990): 218.

26 Newsletter 39 (March 1990): 58.

27 Newsletter 39 (May 1990): 103.

28 Newsletter 36 (January 1987): 12.

29 Newsletter 42 (July 1993): 108.

30 Newsletter 42 (January 1993): 14-15.

31 Newsletter 36 (November 1987): 239.

33 Newsletter 43 (July 1994): 115.

33 Newsletter 42 (May 1993): 73.

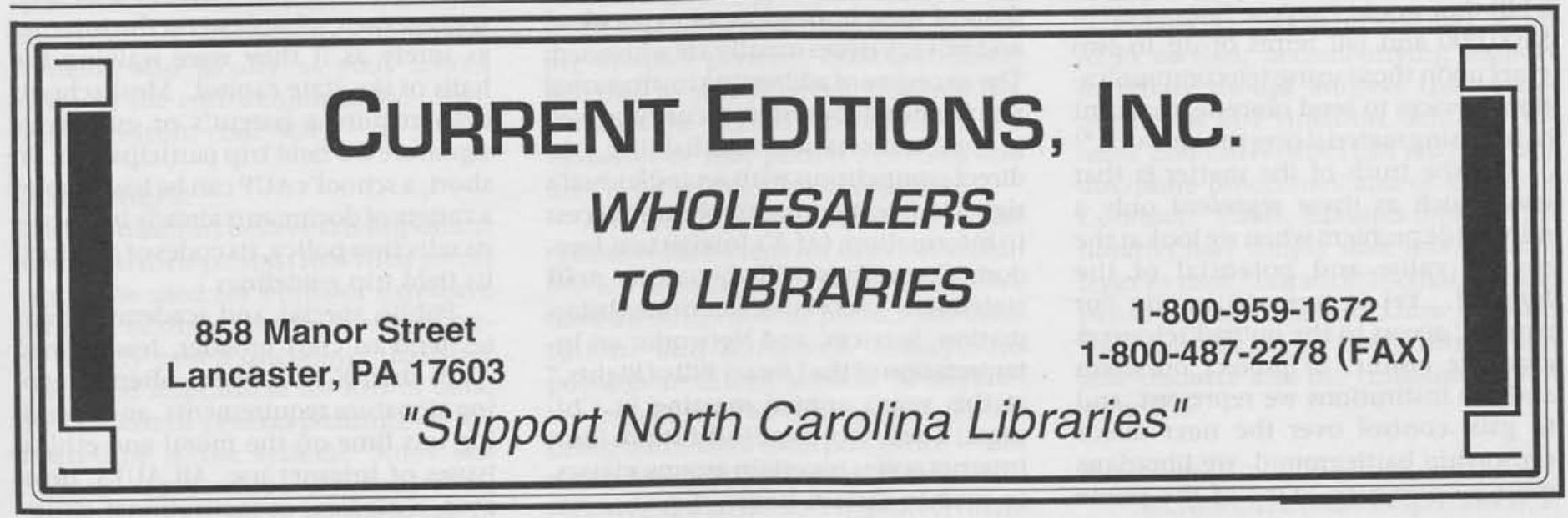

